\title{
Математичне моделювання
} електропідсилювача керма транспортного
засобу з черв’ ячною передачею

\author{
B.I. Скуріхін \\ Харківський національний \\ університет міського господарства \\ імені О.М. Бекетова \\ Україна \\ E-mail: vladscu@gmail.com
}

\author{
К.О. Сорока \\ Харківський національний \\ університет міського господарства \\ імені О.М. Бекетова \\ Україна \\ E-mail: kasoroka@ukr.net
}

\author{
I.В. Агарков \\ Харківський національний \\ університет міського господарства \\ імені О.М. Бекетова \\ Україна \\ E-mail: ivan.aharkov@gmail.com
}

\begin{abstract}
Анотація - Перераховані переваги електропідсилювача в порівнянні 3 гідропідсилювачем керма. Наведено можливі компонування електропідсилювача керма. Виведена формула для розрахунку активного моменту опору, обумовленого кутом поперечного нахилу шворня. Дана система диференціальних рівнянь, що характеризують електропідсилювач керма 3 черв'ячною передачею. Зображена функціональна схема електропідсилювача керма.
\end{abstract}

Ключові слова - рульове керування, електропідсилювач, гідропідсилювач, електродвигун, мікропроцесорна система керування.

\section{I. ПОСТАНОВКА ПРОБЛЕМИ}

В даний час переважна більшість підсилювачів керма, що встановлюються на транспортні засоби, відносяться до розряду гідропідсилювачів. Електропідсилювач керма вже став штатним пристроєм, але поки що для легкових автомобілів.

Для сучасних легкових автомобілів, такі виробники рульового керування, як TRW, Delphi, ZF, Lucas, MGF встановлюють електропідсилювачі керма. Електропідсилювачі керма мають перед гідропідсилювачами ряд переваг [1,2]:

1. Транспортний засіб, оснащений електропідсилювачем керма, витрачає приблизно на 5\% палива менше, ніж такий же, оснащений гідропідсилювачем керма, тому що вмикається в дію тільки при наявності обертального моменту на рульовому колесі.

2. Транспортний засіб, оснащений електропідсилювачем керма, екологічно чистіший, ніж такий же автомобіль, оснащений гідропідсилювачем.

3. Електропідсилювач керма дає можливість легко змінювати ступінь допомоги водієві при зміні швидкості транспортного засобу.
4. Електропідсилювач керма дозволяє легко змінювати характер допомоги водієві в залежності від його індивідуальних вимог.

Аналіз електропідсилювачів рульового керування. Електропідсилювачі керма виробляють в трьох компоновках, які відрізняються місцем докладання допоміжного зусилля $[2,3,5]$ :

1. Зусилля від електричного двигуна через механічну передачу (наприклад, через черв'ячну) прикладається до рульового валу. Це найпоширеніший тип компонування електропідсилювача керма для легких автомобілів (Column Drive EPS).

2. Зусилля від електричного двигуна передається на шестерню редуктора рульового механізму. Така компоновка застосовується для середніх автомобілів (Pinion Drive EPS).

3. Зусилля від електричного двигуна через кулькову гвинтову пару передається на рейку рульового приводу. Ця компоновка застосовується для великих легкових автомобілів і для легких вантажівок (Rack Drive EPS).

Окремо слід згадати про електропідсилювач керма, який діє за принципом електричного валу (drive by wire), коли між рульовим приводом i рульовим механізмом відсутній механічний зв'язок. Поки така компоновка законодавчо заборонена для використання. Однак iї застосування значно спростило б конструкцію рульового керування i алгоритми керування електропідсилювачем керма. Ця заборона мотивується меншою надійністю даної конструкції в порівнянні зі звичайними компоновками та обмеженні функціональності при знеструмлені бортової мережі [2, 4].

Спрощена структурна схема електропідсилювача керма представлена на fig. 1. 


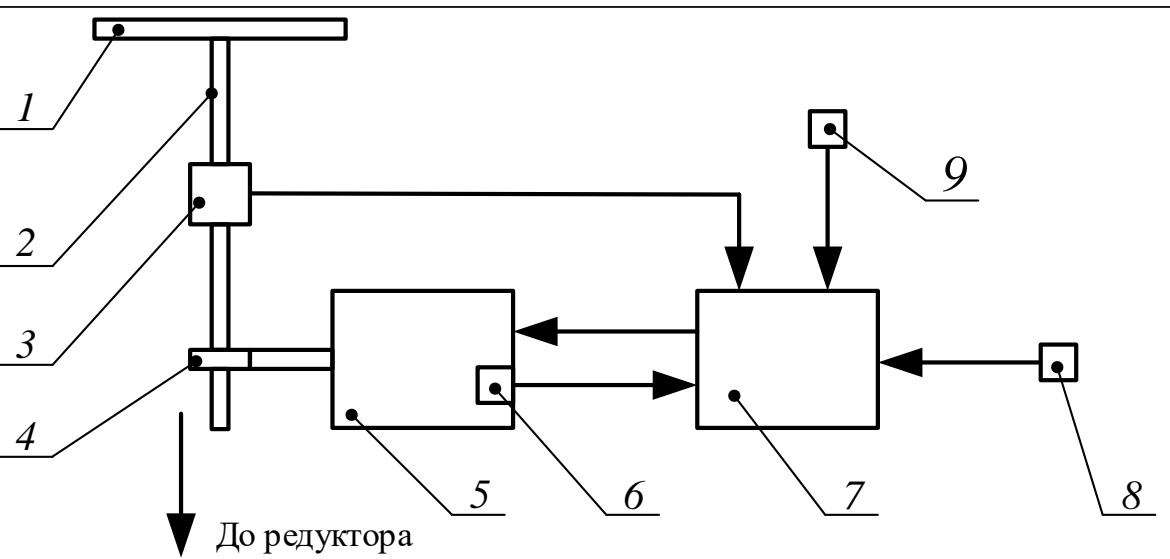

Fig. 1. Структурна схема електропідсилювача керма:

1 - рульове колесо; 2 - рульовий вал; 3 - датчик моменту; 4 - черв'ячна передача;

5 - електричний двигун; 6 - датчик струму; 7 - електронний блок керування; 8 - датчик частоти обертання колінчатого валу; 9 - датчик швидкості транспортного засобу.

У розріз рульового валу вставлений датчик крутного моменту і черв'ячне колесо, яке через черв'як з'єднує рульовий вал з валом електричного двигуна. Напруга від генератора або від акумулятора подається на електричний двигун через електронний блок керування.

Для цього в блоці керування змонтований силовий транзисторний широтно-імпульсний перетворювач, керований від електронного мікропроцесорного контролера. У блоці керування знаходиться датчик струму якоря електродвигуна. Мікроконтролер приймає сигнали від датчика крутного моменту, від датчика струму якоря електродвигуна, від датчика швидкості транспортного засобу і від датчика частоти обертання колінчастого вала. Залежно від цих сигналів мікроконтролер за програмою, записаної в постійному запам'ятовуючому пристрої, формує широтномодульований сигнал керування, що забезпечує необхідний алгоритм роботи електропідсилювача керма.

Треба відзначити, що обов'язковим компонентом більшості електропідсилювачів керма $\epsilon$ датчик положення рульового вала. Наявність цього датчика значно спрощує вирішення багатьох завдань керування i діагностики, зокрема, за допомогою цього датчика легко вирішується проблема самоповернення коліс автомобіля в центральне положення. Однак цей датчик здорожує вартість системи, так як він повинен бути багатооборотним. Крім того, різні виробники використовують різні типи електричних двигунів. В основному використовуються двигуни трьох типів: двигуни постійного струму з збудженням від постійних магнітів (наприклад, КОYО), вентильні електродвигуни (наприклад, Delphi) i реактивні електричні двигуни (наприклад, TRW). Датчики крутного моменту фактично вимірюють кут закручування торсіонного вала, вставленого в розріз рульового вала. Подібні датчики виправдовують свою назву (тобто вимірюють крутний момент, прикладений водієм до рульового колеса) тільки при нерухомому рульовому валі або при сталому обертанні рульового вала. Вимірювання кута закручування здійснюється різними методами, наприклад, на авто сімейства ВАЗ використовується датчик моменту оснований на принципі струмовихрового методу, датчик фірми Honda використовуе вплив кута закручування на магнітну систему диференціального трансформатора, датчик фірми Lucas - оптико-електронний метод $[3,5]$.

Програми керування та діагностики розроблені на основі алгоритмів керування та діагностики. Специфічність об'єкта керування i незвичайність вимог, що пред'являються до системи керування, призводять до того, що інтуїтивні або отримані в результаті стандартних методів розрахунку алгоритми керування виявляються непрацездатними. Поряд зі стандартною вимогою відсутності автоколивань і асимптотичної стійкості замкнутої системи керування висуваються вимоги відсутності тремтіння компенсуючого моменту (torque ripple); відсутності відчуття зубчастості керма (cogging); безшумності роботи електропідсилювача; демпфірування коливань при здійсненні повернення коліс в середнє положення після повороту; інформативності електропідсилювача керма; відсутності "в'язкості" керма; діагностики під час руху і ряд інших. У багатьох випадках ці вимоги суперечать один одному, і вирішення однієї проблеми може посилити іншу проблему. Наприклад, для збільшення допомоги водієві з боку електропідси-лювача керма (для збільшення компенсуючого моменту) потрібно збільшити коефіцієнт посилення регулятора моменту, але це призводить до автоколивань в замкнутій системі. Це стандартна ситуація в замкнутих системах керування i подібна проблема вирішується стандартним способом за допомогою регуляторів або компенсаторів фазового зсуву. Однак при цьому погіршуються інші характеристики системи [5].

Для керування електропідсилювачем керма необхідно використовувати систему зі змінною структурою. Перехід від однієї структури до іншої здійснюється за допомогою експертної системи, що виявляє поточний режим роботи електропідсилювача керма.

Для кожного режиму роботи використовується свій спосіб керування електродвигуном. Інтуїтивні способи 
В.І. Скуріхін, К.О. Сорока, І.В. Агарков Вип.59, №03.

синтезу системи зі змінною структурою можуть зажадати багато часу, сил і засобів, а алгоритми, отримані такими способами, можуть бути неефективними, коли електропідсилювач буде встановлений на транспортний засіб іншої конструкції. Для аналітичного дослідження електропідсилювача керма і синтезу алгоритмів керма необхідно розробити математичну модель електропідсилювача керма, а також цифрову модель електропідсилювача, що реалізує цю математичну модель на комп'ютері i дозволяє проводити попередню оцінку синтезованих алгоритмів керування.

\section{II. МЕТА ДОСЛІДЖЕННЯ}

Складання математичної моделі електропідсилювача керма транспортного засобу з черв'ячною передачею.

\section{III. ВИКЛАД ОСНОВНОГО МАТЕРІАЛУ}

Складання математичної моделі. Електропідсилювач керма містить кілька частин, що вимагають різних підходів до складання математичної моделі: механічну частину, електричний двигун, транзисторний широтно-імпульсний перетворювач, датчик моменту, мікроконтролер. При моделюванні була прийнята тримасова модель механічної частини рульового керування 3 електропідсилювачем керма. Така модель відображає всі характерні особливості рульового керування, і в той же час вона не дуже громіздка. Це розрахункова модель грунтується на приведенні до рульового валу всіх інерційних мас, переміщень і моментів сил. Розрахункова схема механічної частини представлена на fig. 2.

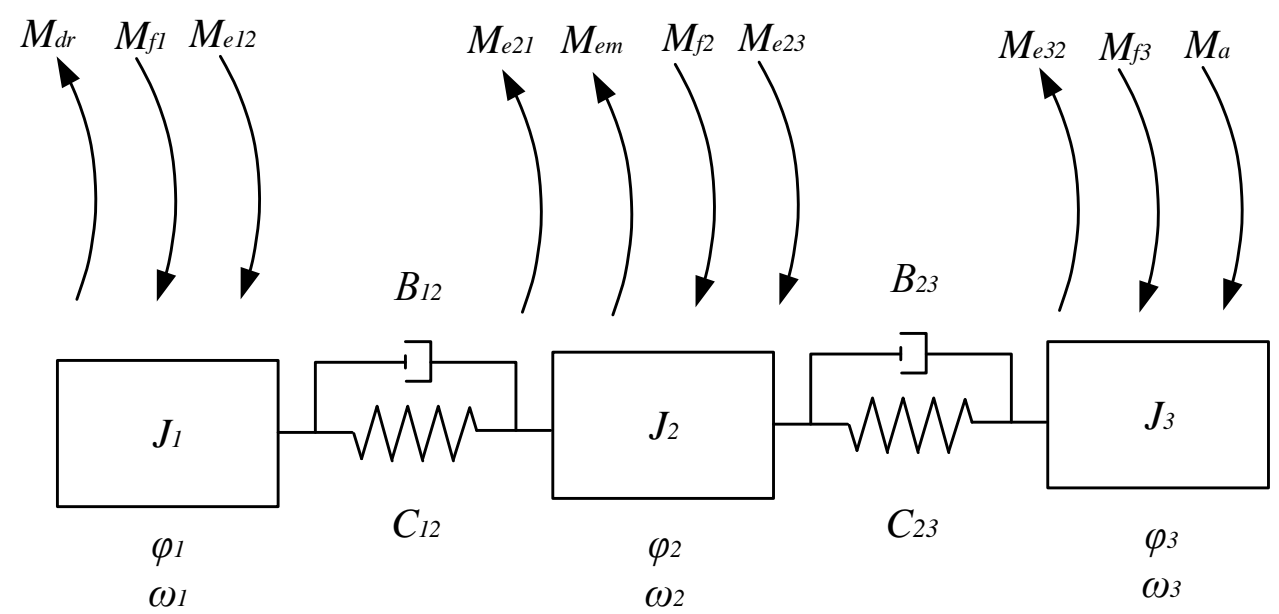

Fig. 2. Розрахункова схема механічної частини електропідсилювача керма

Розглянемо Відповідно до fig.2:

$J_{I}$ - момент інерції рульового колеса і тієї частини рульового валу, яка розташована вище датчика моменту;

$J_{2}$ - сума моменту інерції тієї частини рульового валу, яка розташована нижче датчика моменту, i приведеного до рульового валу моменту інерції якоря електродвигуна $J_{e m}$ i черв'яка $J_{w}$. Враховуючи, що коефіцієнт приведення дорівнює квадрату передавального відношення черв'ячної передачі $K_{w}$, визначається як :

$$
J_{2}=K_{w}^{2} \cdot\left(J_{e m}+J_{w}\right)
$$

$J_{3}$ - сума наведених моментів інерції коліс i рульового приводу. Коефіцієнт приведення дорівнює квадрату відношення кута повороту коліс до кута повороту рульового валу $K_{s d}$; валу;

$\omega_{1}$ - частота обертання верхньої частини рульового валу;

$\omega_{2}$ - частота обертання нижньої частини рульового $\omega_{3}-$ приведена до рульового валу частота обертання коліс навколо осі повороту;

$\varphi_{1}-$ кут повороту верхньої частини рульового валу;

$\varphi_{2}-$ кут повороту нижньої частини рульового валу;

$\varphi_{3}$ - приведений до рульового валу кут повороту коліс навколо осі повороту;

$M_{d r}$ - крутний момент, прикладений водієм до рульового колеса;

$M_{e m}$ - приведений до рульового валу момент електродвигуна, визначається як:

$$
\begin{gathered}
M_{e m}=K_{w} \cdot C_{e} \cdot \Phi \cdot I_{a}=\frac{K_{w} \cdot I_{a}}{K_{e m}} \\
K_{e m}=\frac{1}{C_{e} \cdot \Phi}
\end{gathered}
$$

де $C_{e}$ - конструктивна постійна двигуна постійного струму; 
$\Phi$ - магнітний потік збудження двигуна постійного струму;

$l_{a}-$ струм якоря двигуна постійного струму;

$M_{a}$ - активний момент опору:

$$
M_{a}=M_{a 1}+M_{a 2}
$$

де $M_{a 1}=K_{a} \cdot \sin \left(K_{s d} \cdot \varphi_{3}\right) \quad-$ приведений до рульового валу момент, обумовлений поперечним нахилом осі повороту коліс. Цей момент забезпечує самоповернення коліс в центральне положення після закінчення повороту;

$M_{a 2}$ - приведений до рульового валу момент, обумовлений активним впливом дороги на колеса транспортного засобу, що рухається, наприклад, при бічному наїзді на перешкоду;

$M_{f l}$ - момент тертя в підшипниках верхнього валу рульового керування;

$M_{f 2}-$ приведений до рульового валу момент опору, обумовлений тертям щіток електродвигуна на колекторі і тертям в черв'ячній передачі. Наявність цього моменту призводить до того, що у транспортному засобі оснащеному електропідси-лювачем керма, відсутнє самоповернення коліс після закінчення повороту.

$$
M_{f 2}=K_{f 2} \cdot \operatorname{sgn}\left(\omega_{2}\right)-K_{f w 2} \cdot \omega_{2}
$$

$M_{f 3}$ - приведений до рульового валу момент опору повороту коліс, обумовлений тертям шин об дорогу.
$M_{e 12}$ - момент, обумовлений закручуванням торсіонного валу датчика моменту.

$$
\begin{gathered}
M_{f 3}=K_{f 3} \cdot \operatorname{sgn}\left(\omega_{3}\right)-K_{f w 3} \cdot \omega_{3} \\
M_{e 12}=C_{12} \cdot\left(\varphi_{1}-\varphi_{2}\right)-B_{12} \cdot\left(\omega_{1}-\omega_{2}\right) \\
M_{e 21}=-M_{e 12}
\end{gathered}
$$

$M_{e 23}$ - приведений момент, обумовлений пружними деформаціями рульового приводу i пружними деформаціями шин:

$C_{12}$ - жорсткість торсіонного валу датчика моменту;

$B_{12}$ - коефіцієнт демпфірування пружних коливань торсіонного валу;

$$
\begin{aligned}
M_{e 23}= & C_{23} \cdot\left(\varphi_{2}-\varphi_{3}\right)-B_{23} \cdot\left(\omega_{2}-\omega_{3}\right) \\
& M_{e 32}=M_{e 23}
\end{aligned}
$$

$C_{23}$ - приведена жорсткість шин i рульового приводу;

$B_{23}$ - приведений до рульового валу коефіцієнт демпфірування пружних коливань рульового приводу і шин.

Наведемо висновок формули для розрахунку активного моменту опору $M_{a l}$, обумовленого кутом $\alpha$ поперечного нахилу шворня.
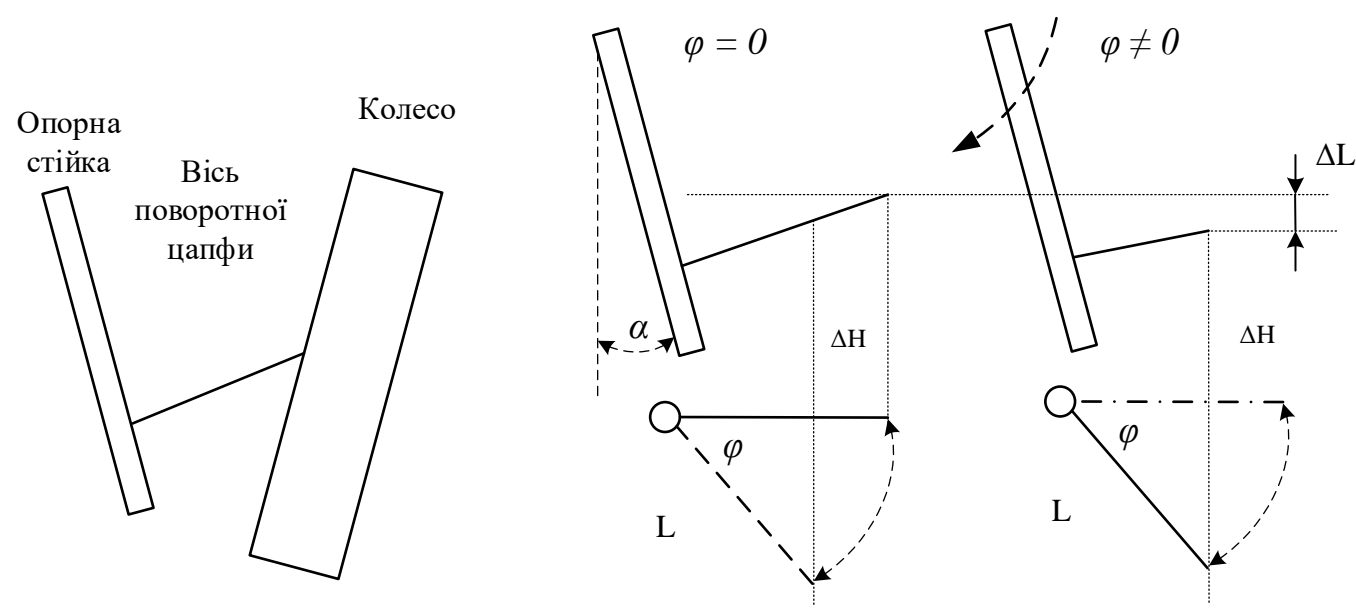

Fig. 3. Визначення положення кінця осі поворотної цапфи при повороті шворня

При нульовому куті повороту коліс $\varphi$ потенційна енергія системи "кузов-колеса" мінімальна, так як при цьому кузов розташовується ближче до землі. При повороті шворня вона одночасно піднімається над землею і піднімає кузов. Визначимо зміну положення кінця осі поворотної цапфи при повороті шворня на кут $\varphi$.

Нехай довжина осі поворотної цапфи дорівнює $L$, а кут поперечного нахилу осі шворня дорівнює $\alpha$, тоді при повороті шворня на кут $\varphi$ кінець осі поворотної цапфи опустився б на величину $\Delta L$, але так як земля не дозволяє колесу опускатися нижче її поверхні, то на цю величину піднімається шворінь, а разом 3 ним піднімається кузов. Кузов підніметься на величину, відмінну від розрахункової, так як між кузовом i шворнем існують амортизуючі елементи. 
В.І. Скуріхін, К.О. Сорока, І.В. Агарков Вип.59, №03.

$$
\begin{gathered}
\frac{L-\Delta H}{L}=\cos (\varphi) \\
\Delta H=L \cdot(1-\cos (\varphi))
\end{gathered}
$$

Якщо кут між шворнем і поворотною цапфою дорівнює $90^{\circ}$, то

$$
\Delta L=\Delta H \cdot \sin (\alpha)=L \cdot \sin (\alpha) \cdot(1-\cos (\varphi))
$$

Зміна потенційної енергії

$$
\Delta W=G_{w} \cdot \Delta L=G_{w} \cdot L \cdot \sin (\alpha) \cdot(1-\cos (\varphi))
$$

Тут $\mathrm{G}_{\mathrm{w}}$ - вага транспортного засобу, що припадає на одне колесо. Момент, що перешкоджає повороту шворню, запишеться як:

$$
M_{a 1}=\frac{\partial f W}{\partial \varphi}=G_{w} \cdot L \cdot \sin (\alpha) \cdot \sin (\varphi)
$$

Позначимо кута $\varphi$ повороту шворня (і колеса) до кута $\varphi_{3}$ повороту рульового валу як $K_{s d}$, тоді формула для обчислення $\mathrm{M}_{\mathrm{a} 1}$ запишеться в наступному вигляді

$M_{a 1}=2 \cdot K \cdot G_{w} \cdot L \cdot \sin (\alpha) \cdot \sin \left(K_{s d} \cdot \varphi_{3}\right)=K_{a} \cdot \sin \left(K_{s d} \cdot \varphi_{3}\right)(16)$

$$
\left\{\begin{array}{c}
J_{1} \frac{d^{2} \varphi_{1}}{d t^{2}}=M_{d r}-K_{f 1} \cdot \omega_{1}-C_{12} \cdot\left(\varphi_{1}-\varphi_{2}\right)-B_{12} \cdot\left(\omega_{1}-\omega_{2}\right) \\
J_{2} \frac{d^{2} \varphi_{2}}{d t^{2}}=\frac{K_{w} \cdot I_{a}}{K_{e m}}-K_{f w 2} \cdot \omega_{2}-K_{f 2} \cdot \operatorname{sgn}\left(\omega_{2}\right)+C_{12} \cdot\left(\varphi_{1}-\varphi_{2}\right)-B_{12} \cdot\left(\omega_{1}-\omega_{2}\right)- \\
\quad-C_{23} \cdot\left(\varphi_{2}-\varphi_{3}\right)-B_{23} \cdot\left(\omega_{2}-\omega_{3}\right) \\
J_{3} \frac{d^{2} \varphi_{3}}{d t^{2}}=-K_{f 3} \cdot \operatorname{sgn}\left(\omega_{3}\right)-K_{f w 3} \cdot \omega_{3}+C_{23} \cdot\left(\varphi_{2}-\varphi_{3}\right)-B_{23} \cdot\left(\omega_{2}-\omega_{3}\right)-K_{a} \cdot \sin \left(K_{s d} \cdot \varphi_{3}\right)
\end{array}\right.
$$

Оскільки механічна інерційність, кут повороту валу i момент, що розвивається електродвигуном, вже враховані в другому рівнянні системи (18), для завершення математичного опису електродвигуна досить записати рівняння Кірхгофа для якірного ланцюга електродвигуна.

$$
L_{a} \cdot \frac{d i_{a}}{d t}+i_{a} \cdot R_{a}=u_{p w m}-E
$$

де $L_{a} \quad-$ індуктивність якірного ланцюга електродвигуна;

$I_{a}$ - струм якірного ланцюга електродвигуна;

$R_{a}$ - опір якірного ланцюга електродвигуна;

$u_{p w m}$ - ефективна напруга широтно-імпульсного перетворювача;

$E$-проти-ЕРС електродвигуна.

Перепишемо рівняння (19) в нормованому вигляді:
Коефіцієнт 2 з'являється у формулі з огляду на те, що момент опору створюють два колеса. Беручи до уваги той факт, що внутрішнє і зовнішне колеса при повороті повертаються на різний кут, то точна формула для розрахунку $\mathrm{M}_{\mathrm{a} 1}$ буде мати більш складний вигляд (або треба буде розраховувати окремо моменти для внутрішнього і зовнішнього колеса). Для розрахункової схеми (fig. 2) 3 ураху-ванням прийнятих позначень запишемо рівняння Ньютона в формі, що використовується при вивченні обертального руху.

$$
\left\{\begin{array}{l}
J_{1} \frac{d \omega_{1}}{d t}=M_{d r}-M_{f 1}-M_{e 12} \\
J_{2} \frac{d \omega_{2}}{d t}=M_{e m}-M_{f 2}+M_{e 12}-M_{e 23} \\
J_{3} \frac{d \omega_{3}}{d t}=-M_{f 3}-M_{e 32}-M_{a}
\end{array}\right.
$$

Враховуючи, що $\frac{d \omega_{i}}{d t}=\frac{d^{2} \varphi_{i}}{d t^{2}}$ а також беручи до уваги формули для визначення деяких моментів, розташованих в правій частині системи (17), перепишемо цю систему в новому вигляді:

$$
T_{e} \cdot \frac{d i_{a}}{d t}+i_{a}+\frac{K_{w} \cdot \omega_{2}}{K_{e m} \cdot R_{a}}=\frac{u_{p w m}}{R_{a}}
$$

Датчик моменту складається $з$ торсіонного вала, що перетворює крутний момент в кут закручування, i 3 пристрою, що перетворює пружну деформацію торсіонного вала в електричний сигнал. Торсіонний вал вмонтований в розріз рульового валу. Кут закручування торсіонного вала не перевершує $\pm 3^{\circ}$. Це досягається за рахунок того, що на кінцях рульового вала, які з'єднує торсіонний вал, $\epsilon$ вінці, що знаходяться в зачепленні один 3 одним. Між зубами цих вінців залишений повітряний зазор величиною $3^{\circ}$. Після того як торсіон закрутиться на $3^{\circ}$, повітряний зазор буде обраний, зуби вінців увійдуть в зачеплення один 3 одним і зусилля буде передаватися не через торсіон, а через вінці. Це є запобіжником торсіона від поломки. 3 огляду на вищевикладене, а також те, що електронна частина датчика моменту має інерційність, рівняння для вихідної напруги датчика моменту запишемо у вигляді: 


$$
T_{t s} \cdot \frac{d u_{t s}}{d t}+u_{t s}=K_{t s} \cdot\left(\varphi_{1}-\varphi_{2}\right)
$$

До системи (18) треба додати умову, що обмежує по модулю кут закручування торсіона для запобігання його виходу з ладу:

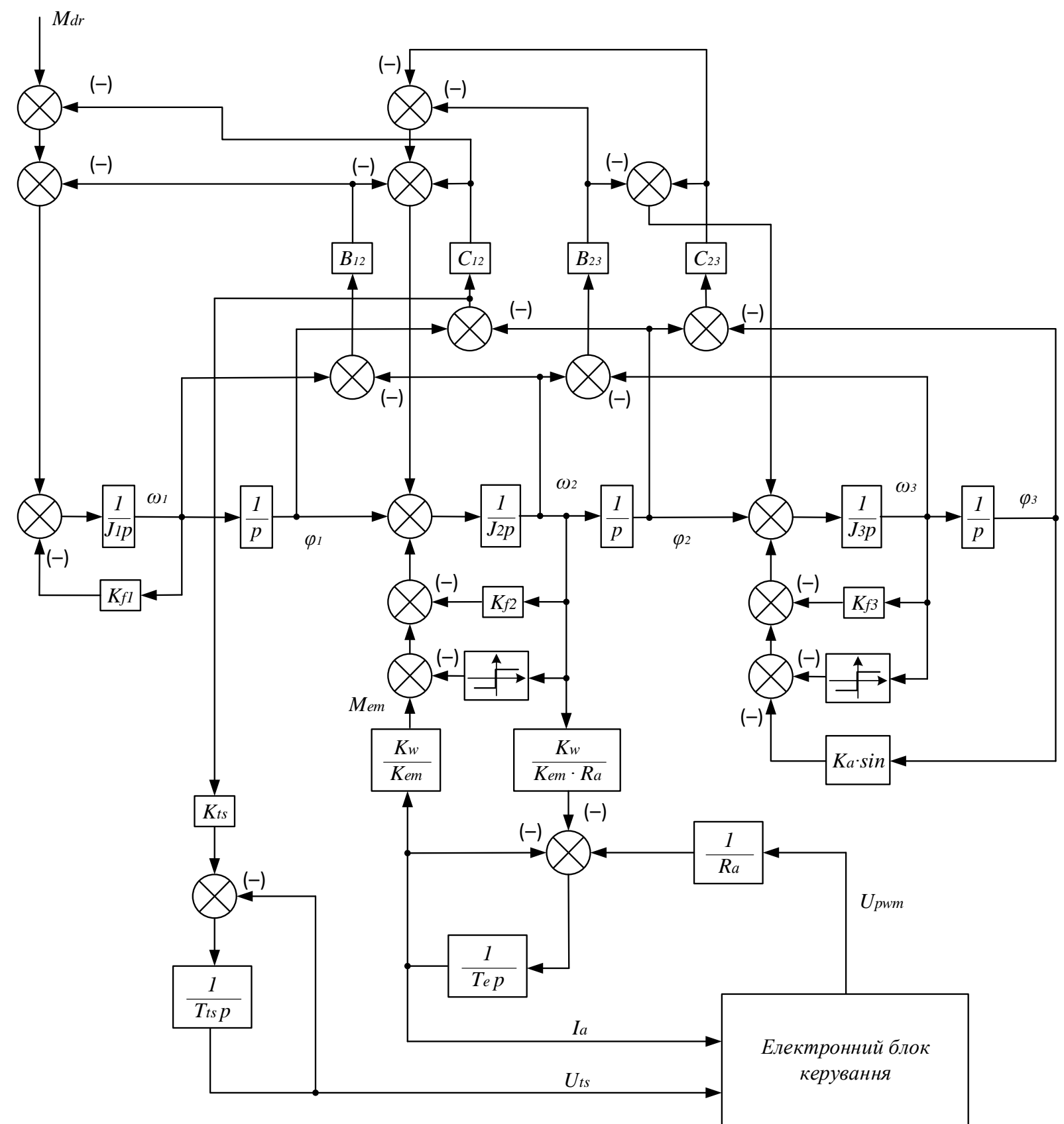

Fig. 3. Функціональна схема електропідсилювача керма з черв'ячною передачею

IV. Висновки

На підставі вищенаведених рівнянь була розроблена функціональна схема системи керування електропідсилювачем керма, яка $\epsilon$ уніфікованою для систем рульового керування 3 черв'ячною передачею і може послужити базовою для моделювання системи рульового керування вантажних та пасажирських транспортних засобів (автобусів, тролейбусів).

$$
\operatorname{abs}\left(\varphi_{1}-\varphi_{2}\right)<\frac{\pi}{60}
$$

Ha fig. 4 представлена функціональна схема електропідсилювача керма з черв'ячною передачею 
В.І. Скуріхін, К.О. Сорока, І.В. Агарков Вип.59, №03.

[4] Козловський В.Н., Малєєв Р.А. Прогнозирование стабильности технических характеристик электромеханического усилителя рулевого управления автомобиля // Грузовик. - 2008. - № 1. - С. 13-15.

[5] Козловський В.Н., Малєєв Р.А. Анализ автомобильного электромеханического усилителя рулевого управления // Грузовик. - 2008. - № 12. - С. 37-38.

[6] Огороднов С.М., Синичкин С.Г. Расчет усилителя рулевого управления с шаговым электродвигателем для транспортных средств // Труды НГТУ им Р. Е Алексеева. - 2012. - № 4. C. $182-191$.

[7] Павленко Т.П., Скуріхін B.І., Колотило В.І., Агарков I.В. Аналіз проблем системи рульового керування тролейбусів та

перспективи їх вирішення // Збірник наукових праць ДУІТ, Серія «Транспортні системи і технології». - 2018. - Вип. 32. С. $115-123$.

[8] Ященко Д.М. До визначення моментів, що діють на керуючий колісний модуль автомобіля // Управління проектами, системний аналіз і логістика. Технічна серія. - 2011. - Вип. 8. - C. 229-234.

[9] Солтус А.П., Клімов Е.С. Дослідження моменту опору повороту шини керованого колеса на місці залежно від довжини цапфи // Вісник Кременчуцького національного університету імені Михайла Остроградського. - 2012. - №4. C. $88-93$.

\section{Mathematical modeling of the electric power steering system of a vehicle with a worm drive}

\author{
V. Skurikhin \\ O.M. Beketov National University of \\ Urban Economy in Kharkiv, \\ Ukraine
}

\author{
K. Soroka \\ O.M. Beketov National University of \\ Urban Economy in Kharkiv, \\ Ukraine
}

\author{
I. Aharkov \\ O.M. Beketov National University of \\ Urban Economy in Kharkiv, \\ Ukraine
}

The complexity and variety of requirements imposed on modern cars have led to a variety of designs of steering amplifiers, which are based on various physical phenomena and patterns (mechanical, pneumatic, hydraulic, electrical, etc.). Despite the difference in design and operating principles, steering amplifiers of domestic and foreign production are based on a large number of complex components and parts, which reduces their reliability. In addition, due to the constant impact of amplifiers on the controlled wheels, the driver does not feel changes in the behavior of the car on the road when disturbing influences occur, which reduces traffic safety and can lead to an accident. Therefore, increasing the sensitivity of the steering wheel to adverse factors acting on the wheels of the car while driving is one of the important tasks of improving power steering system.

Introduction of electric power steering systems for cargo and passenger vehicles with a load capacity of up to 20 tons. this is a very urgent problem. In contrast to power steering system, which is still used in the control systems of high-tonnage vehicles, electric power is much simpler in design, does not require much time and costs for operation and repair.

Electric power steering system with worm drive, which has a gear ratio significantly higher than those used in passenger cars, is considered. For this purpose, the formula for calculating the active moment of resistance due to the angle of transverse inclination of the pin and the corresponding system of differential equations characterizing the electric power steering system with worm drive are derived. Based on this, a functional diagram of the electric power steering control system has been developed, which is unified for worm drive steering systems and can serve as a base for modeling the steering system of cargo and passenger vehicles.

Keywords - steering, electric power, power steering, electric motor, microprocessor control system. 